\title{
When focus goes wild: An empirical study of two syntactic positions for information focus ${ }^{*}$
}

\author{
Ángel L. Jiménez-Fernández \\ University of Seville, Spain
}

\begin{abstract}
My goal in the present paper is to carry out an analysis of the syntactic and discourse properties of Information Focus (IF) in Southern Peninsular Spanish (SPS) and Standard Spanish (SS) varieties. Generally, it has been argued that IF tends to occur last in a sentence since new information is placed in final position, following the End-Focus Principle as well as the Nuclear Stress Principle (Zubizarreta 1998). Focus fronting has been hence reserved for those cases in which a clear contrast between two alternatives is established, namely Contrastive Focus (CF) and Mirative Focus (MF) (cf. Cruschina 2012). The starting hypothesis here is that IF can appear as a fronted element in a sentence and that SPS speakers show a higher degree of acceptability and grammaticality towards such constructions, as opposed to SS speakers. This points toward a certain degree of microparametric variation in Spanish syntax (an understudied area), which will be tested by means of a grammaticality judgement task run among both SPS and SS speakers.
\end{abstract}

Keywords: Southern Peninsular Spanish, Standard Spanish, information focus, mirative focus, contrastive focus, focus fronting

\section{Introduction}

This paper explores the discourse-syntax properties of a specific type of focus construction in Spanish, namely Information Focus (IF) Fronting. It has been generally asserted that Spanish lacks this type of discourse-based movement on the basis that the focus found in the Left Periphery (LP) of a sentence always conveys some sort of contrast, thereby instantiating what is termed as Contrastive Focus (CF). Cruschina (2012) explicitly groups Italian and Spanish together in that both can have Focus Fronting only if it bears a contrastive flavour, following

\footnotetext{
* I am very grateful to Silvio Cruschina, Maria del Mar Vanrell, Javi Fernández, Emilio Servidio, Francesc González i Planas, and especially Iván Ortega-Santos. My discussion with them all has definitely contributed to improve this paper. I am also thankful to the two anonymous reviewers of Linguistics Beyond and Within for their helpful and insightful comments and suggestions. This research has been partially funded by the Project FFI2013-41509-P of the Spanish Ministry of Economy and Competitiveness.
} 
Rizzi (1997) for Italian, and Zubizarreta $(1998,1999)$ and López (2009) for Spanish. This is illustrated in (1).

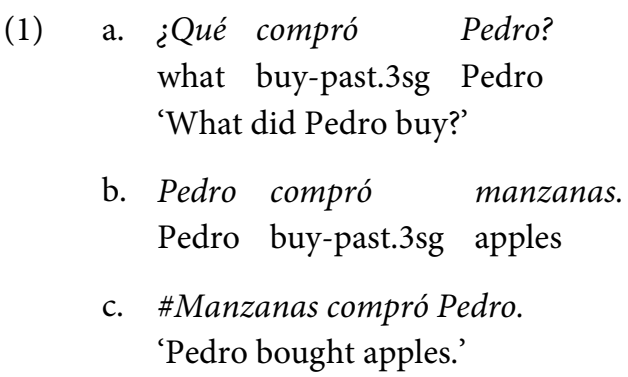

As indicated by \#, sentence (1c) is regarded as non-felicitous. It is not acceptable as an answer to (1a). The reason provided in the literature is that in Spanish Information Focus must always be post-verbal, and when focus is preposed it expresses contrast. ${ }^{1}$

I show that the unacceptability of examples such as (1c) is subject to microparametric variation (sensu Roberts 2012 and Biberauer et al. 2010). Some varieties of Spanish (Southern Peninsular Spanish, including Andalusian and Extremaduran Spanish) seem to obviate the post-verbal condition on Information Focus. I discuss the syntax of different types of focus, namely Contrastive/Corrective Focus (CF), Mirative Focus (MF) and Information Focus (IF), and propose that Information Focus has a designated position in the left periphery in SPS, which is missing in Standard Spanish (SS). Information focus fronting is an understudied phenomenon in Spanish, as clearly shown by the new data presented here. ${ }^{2}$

Descriptive surveys such as the one carried out by RAE-ASALE do not take into account the different types of focus and include all kinds of fronting within a single group regardless of the distinct salient properties at the syntactic, interpretive and phonological levels. In this group phenomena are mixed up such as Contrastive Focus, Mirative Focus (Cruschina 2012; Jiménez-Fernández 2015), Resumptive Preposing (RP; Cinque 1990, Leonetti \& Escandell 2009), and Quantifier Fronting/Negative Preposing (QF; Barbosa 2001; Bosque 1980). Researchers have agreed that in all these cases contrast is present:

(2) a. ¡Por Dios, dos botellas se han bebido! (MF, adopted from Cruschina 2012)

by god, two bottles CL have-pres.2pl drunk

'My God! They have drunk up two bottles!'

b. Lo mismo digo (yo). (RP, Leonetti and Escandell 2009: 160)

the same say-pres.1sg (I)

'I say the same thing.'

c. Algo tendrán que hacer ustedes. (QF, RAE-ASALE 2009/2011:2988)

something have-fut.3pl that to.do you-pol.pl

'You will have to do something about it'.

\footnotetext{
The subject moves to preverbal position for independent reasons concerning syntax. In this respect, it may seem that a preverbal subject is in a discourse position such as focus, but in fact it occupies a syntactic position such as spec-TP.

2 Microvariation in syntax is an emerging field today. With respect to focus, Information focus fronting has been attested in Sardinian (Cruschina 2012; Remberger 2014), in Balearic Catalan and Spanish as spoken in the Basque Country (Vanrell and Fernández-Soriano 2013), etc. My goal in this respect is to contribute to this emerging fied with new data from SPS.
} 
Studies in generative grammar have emerged that distinguish some of these Information Structure (IS) phenomena (Bianchi 2012, Cruschina 2012, Haegeman 2012). In Spanish, some works have identified focus preposing other than purely contrastive (Uriagereka 1988, Quer 2002, Gallego 2007, Leonetti \& Escandell 2009), yet all these analyses agree that Spanish focus fronting is never associated with purely new information. Fronting is a device used to express either contrast on a specific constituent or on the sentence polarity (Verum Focus).

In this work, I show that interpretative and syntactic properties can be used to establish a more accurate typology of focus, concentrating on the peripheral position that IF can fill in some varieties of Spanish (Andalusian, Extremaduran). ${ }^{3}$ An experiment is conducted among speakers in which they have to judge the grammaticality of fronted focus constructions.

In this grammaticality judgement task, informants were faced with examples in which IF occurred in post-verbal position and in the LP. The (A) sentences below provide the context where the informants have to rightly place the sentences that follow:

$$
\begin{aligned}
& \text { A. El chocolate que había puesto en la nevera ya no está. } \\
& \text { the chocolate which have.past.1sg put in the fridge already not be-pres.3sg } \\
& \text { ¿Quién lo ha cogido? } \\
& \text { who it have.pres.3sg taken } \\
& \text { 'The chocolate bar I had put in the fridge is no longer there. Who has taken it?' }
\end{aligned}
$$

$\begin{array}{lll}\text { ¿Quién } & \text { lo ha } & \text { cogido? } \\ \text { who } & \text { it have.pres.3sg } & \text { taken }\end{array}$

B: a. Lo cogió Pedro, y se lo ha $\begin{aligned} & \text { comido todo. } \\ & \text { it take.past.3sg Pedro, and CL it have.pres.3sg eaten all }\end{aligned}$
b. Pedro lo cogió, y se lo ha comido todo. ${ }^{4}$
'Pedro took it, and has eaten it all.'

The informants were divided into 2 different groups. The first group includes areas from northern Spain and Madrid (this is what I will call Standard Spanish ${ }^{5}$ ), whereas the second group comprises the south (corresponding with Southern Peninsular Spanish). It will be shown that SPS speakers accept focus fronting when this focus conveys purely new information, whereas SS do not allow naturally for this type of focus fronting. This confirms the microparametric distinction argued for in this paper.

3 For a full description of other types of focus in terms of Contrastive and Mirative Focus, Quantifier Fronting and Resumptive Preposing, see Jiménez-Fernández (2015) and references therein. Throughout the paper I will assume that focus fronting targets the $\mathrm{CP}$ area, which is the standard view of the left periphery. However, the reader is referred to Camacho-Taboada and Jiménez-Fernández (2014) for an analysis of focus fronting as movement to spec-TP.

4 In the data I have used examples in which the IF is part of a full sentence, thus avoiding what seems to be the most natural option, namely the elliptical clause. However, I have tried to avoid the word-by-word repetition of the question in the answer, since this would add to the clumsy flavour that answers echoing the material in the question have for speakers.

In addition, I assume that (at least some) pre-verbal subjects are placed in the CP-domain, sitting in an A'position (Alexiadou and Anagnostopolou 1998; Barbosa 1995; Frascarelli 2007; among others). However, I depart from these authors in that I claim that this is not a topic position, rather it is a focus position.

5 The term Standard Spanish refers to the standard variety of Spanish as spoken in the Iberian Peninsula. I am not taking into account American varieties, but surely to have a wider view of Focus Fronting. American varieties will be paid attention to in my future research. 
The article is organised as follows. In section 2 I discuss the different types of fronted foci that can be found in the LP. In section 3 I present the data and the test run among Spanish speakers. Section 4 discusses the results of the test. Section 5 summarises my main findings.

\section{The focused constituent: different types of Focus}

The label Focus is often applied to phrases performing two discourse functions, namely (a) the introduction of new information (IF) and (b) the introduction of a contrast (CF) (Kiss 1998). A number of scholars have argued in favour of a clear-cut distinction between these discourse categories, based on syntactic, phonetic, phonological and discourse factors (cf. Kiss 1998, Zubizarreta 1998, Nespor \& Guasti 2002, Donati \& Nespor 2003).

Cross-linguistic evidence supports the necessity of a distinction between different types of Focus, which is syntactically encoded (cf. Molnár 2006, Bentley 2007, Cruschina 2012, Bianchi \& Bocci 2012, Bianchi 2013), and differently interpreted at the interfaces (Frascarelli \& Ramaglia 2013).

Within Generative Grammar two main approaches to the notion of focus can be found. In the Alternative Semantics approach (Rooth 1992, Beaver \& Clark 2008), Focus generates a set of alternatives: given a question like "What does John want?", a set of propositions varying in the reference of the focused direct object ( $\{J o h n$ wants coffee, John wants tea, ... $\}$ ) constitutes congruent answers to it.

On the other hand, the Structured Meaning approach (Krifka 2006) instead partitions the proposition into a Focus (e.g., 'coffee' in the example above) and a background (the denotation of the rest of the clause, i.e. the property of being something that John wants).

When the different types of focus are addressed, we are confronted with different semantic operations, which are reflected in the syntactic derivation. Hence I concentrate on both interpretive and syntactic properties which are used to distinguish the type of foci.

\subsection{Information Focus}

According to the Structured Meaning approach (Krifka 2006), question-answer congruence requires that the Focus in the answer should correspond to the interrogative phrase of the question, and that the backgrounds should be identical. The element in the answer satisfying the information request in the question constitutes new information. This is illustrated in (12):

(4)
A: ¿A quién viste en la playa?
to whom saw-past.2sg at the beach
'Who did you see at the beach?'
B: Vi a Marta.
saw-past.1sg to Marta
'I saw Marta.'

In this dialogue the information provided by the object a Marta in the answer fully satisfies the information request in the question, and hence it stands as the Information Focus (IF). 
This focus is usually placed in final position in Spanish, as claimed by Zubizarreta (1998), Gutiérrez Bravo (2008) and López (2009).

\subsection{Mirative Focus}

Following Cruschina (2012), Bianchi et al. (2014, to appear) and Jiménez-Fernández (2015), I consider Mirative Focus (MF) as not purely informative. It provides new information and additionally, based on the speaker's knowledge of the hearer's expectations, signals that such information will be unexpected (see Piera 1987 for an earlier approach to this type focus):

(5) ¡No me lo puedo creer! ¡Dos botellas nos hemos bebido!

not me it can-pres.1sg believe Two bottles CL have-pres.1pl drunk

'I can't believe it! Two bottles we drank!'

Âmbar (1999: 41) terms a similar kind of fronting in Portuguese as evaluative construction, involving the fronting of an emphatic and evaluative element to a dedicated functional projection (i.e., the Evaluative Phrase) in the left periphery. Due to its unexpectedness, MF has some exclamative flavour

Mirative is not dependent on a question-answer context. Contrast is established with an element that is part of the shared knowledge of the participants and can be semantically characterized as a "proposal to negotiate a shared evaluation" (Bianchi 2012). The set of alternatives is therefore very large. In example (5), the DP dos botellas stands as one alternative among many other alternatives.

\subsection{Corrective/Contrastive Focus}

When Focus marks a constituent that is a direct rejection of an alternative, either spoken by the speaker himself ('not A, but B') or by the hearer, the Focus is 'Corrective'. Correction thus implies removal of information (cf. among others Gussenhoven 2007), as seen in (6), and can also apply to given material, as illustrated in (7):

(6) A: I heard you met Fred yesterday.

B: No, I met Bill.

(7) A: I know John is going on vacation with Fred and Bill.

B: No, he's only leaving with Bill.

Correction implies a Focus-Background partition and the set of alternatives is very restricted (limited by the semantic properties of the rejected item). However, this type of Contrast may not be associated with a corrective import, as is shown in (8) from Frascarelli \& JiménezFernández (2013) and (9) from Kratzer (2004):

(8) My doctor is always so late that a newspaper is not enough: you can read a novel from Tolstoj while you wait!

(9) A: Guess what? Fred passed.

B: If Fred passed, bar exams have become too easy. 
Pure Contrast implies a Focus-Background partition (which can be created by the sentence itself) and the set of alternatives is restricted. In Romance languages, CF has a specific position in the LP. ${ }^{6}$ This is illustrated from Spanish in (10) from Hernanz (2011: 251, her (3a)):

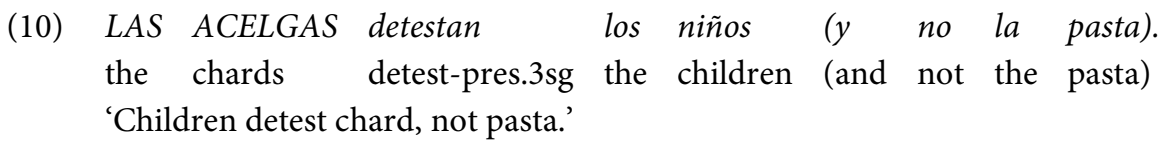

As stated earlier, it is generally assumed that the focus position in the LP is for CF. Recall that MF can also occupy a focus position in the LP (see Cruschina 2012, Bianchi et al. 2014, to appear, and Jiménez-Fernández 2015 for crucial differences between CF and MF). However, IF has been claimed to always occupy a low position. Ortega-Santos (2005) and JiménezFernández \& İşsever (2012) suggest that this position is the specifier of vP; cartographic analyses such as the one in Belletti (2004) argue for a designated Focus position in the low periphery. I leave this question aside since it does not affect the work presented here, but see Ortega-Santos (forthcoming) or Ortega-Santos (2013) for a fuller overview of the derivational alternatives that have been put forward for subjects at the right edge.

Arguably, Focus is encoded as a syntactic feature [+Focus] which characterises all types of focus, and conveys purely new information. The distinction of types is realised by different combinations of features (a general line pursued by Jiménez-Fernández 2015):

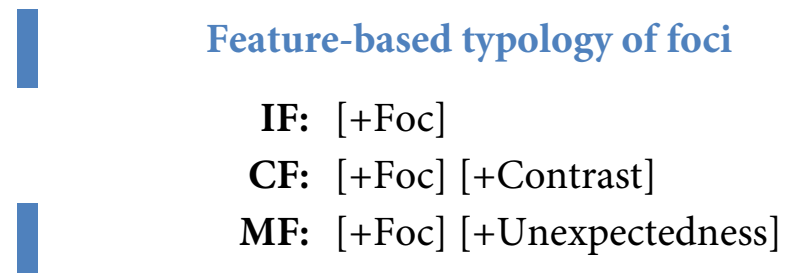

Figure 1: Feature-based typology of foci

Note that I am taking a syntactic approach to Focus. Not all authors agree with this. However, this is a plausible implementation and the exact details do not have any bearing on the argumentation of the paper.

\section{Methodology and data}

Recall that my working hypothesis is that in Southern Peninsula Spanish IF can also occur in a high position at the LP. To prove the validity of this hypothesis, a test has been created for a systematic interface analysis of Focus Fronting (FF), for Mirative, Corrective/Contrastive Foci, but most especially for IF both in situ and fronted in two varieties of Spanish: Southern Peninsular Spanish (SPS, Andalusian and Extremaduran) and Standard Spanish (SS, roughly standing for Northern Iberian Spanish, including Asturian Spanish, Catalan Spanish, Basque Spanish, and Madridian).

\footnotetext{
6 Though contrast can be expressed in several other positions in the sentence, in this paper I deal with focus fronting to the CP system as shown in Rizzi (1997) and Zubizarreta (1998), among others.
} 
It is really complicated to identify what can be called Standard Spanish, as argued in RAEASALE (2009/2011), but given the unifying character of Spanish in general, it is taken to be the variety spoken by educated people in all dialects (though I am not taking into account American varieties). The divide between SS and SPS should thus be seen as geographically and linguistically motivated (see Alvar 2004, for the defining properties of SPS).

In the survey, all types of focus to be examined here have been taken into consideration. FF with the specific discourse functions of CF and MF have been systematically compared with FF with an IF function on purpose. In-situ IF has also been tested to make sure that informants were giving the right pragmatic interpretation to the relevant sentences.

Informants (27 SPS and 33 SS native speakers) were given a set of sentences preceded by a context inducing a specific focus reading of the preposed or in-situ constituent (judgments could be expressed as ${ }^{*} /$ ??/OK). In short, the experiment was a grammaticality judgment task using a '3-point scale'. This was presented in writing. In particular, a sentence introducing the context was provided for speakers to react. This created the environment to induce the appropriate focus interpretation of both preposed and non-fronted foci. Speakers were confronted with sentences in a random order to avoid any sort of predetermined pattern in their answers.

In the examples of the experiment, sentences A constitute the stimulus context and focused constituents in sentences B are underlined. For presentation in this work, I have grouped sentences depending on the type of focus and the type of FF involved. Also the object/subject asymmetry has been taken into account since movement of subjects does not necessarily have an impact on the linear ordering of sentence constituents. Subjects may move to spec-TP for reasons not to be connected with discourse. Alternatively, subjects may move to the $\mathrm{CP}$ area when they have a specific role in discourse. Both possibilities will yield the same word order for preverbal subjects.

Examples (B) contain post-verbal focus, whereas those in (B') comprise preverbal focus. For the stimulus sentence I just provide the English translation, but for the sentences to be judged I offer both the gloss and the translation.

\section{Subject as IF:}

(11) A: El chocolate que tenía escondido ya no está. ¿Quién lo ha encontrado?

'The chocolate I had hidden is not there anymore. Who has found it?'

B: Lo encontró Limena. $Y$ se lo ha comido entero.

it find-past.3sg Jimena and CL it have-pres.3sg eaten all

B': Limena lo encontró. $Y$ se lo ha comido entero.

Jimena it find-past.3sg and CL it have-pres.3sg eaten all 'Jimena found it. And she has eaten it all.'

\footnotetext{
Note that experimental work usually makes use of 7-point Likert scale (Sprouse and Almeida 2011). I have used just three options. My goal was to gather data (of an understudied variety [SSP]) rather than contributing to a specific debate in experimental literature on language processing.
} 
(12) A: ¿Quiénes van este fin de semana a la playa?

'Who is going to the beach this weekend?'

B: Va $\underline{\text { toda }} \underline{\text { la }}$ familia.

go-pres.3sg all the family

B': Toda la familia va.

all the family go-pres.3sg

'All the family is going.'

(13) A: ¿Quién ha ganado el Premio Planeta este año?

'Who has won the Planeta Prize this year?

B: Lo ganado Lorge Zepeda.

it win-past.3sg Jorge Zepeda

B': Lorge Zepeda lo ha ganado.

Jorge Zepeda it win-past.3sg

'Jorge Zepeda won it.'

\section{Object as IF:}

(14) A: ¿Qué está comiendo Ángela?

'What is Angela eating?'

B: Está comiendo pasta.

be-pres.3sg eating pasta

B': Pasta está comiendo.

pasta be-pres.3sg eating

'She is eating pasta.'

(15) A: ¿A quién viste en la fiesta?

'Who did you see at the party?'

B: Vi $\quad \underline{\text { Manuela }}$ pero no me sorprende porque la organizaba Pablo. see-past.1sg to Manuela but not CL surprise-pres.3sg because it organise-past.3sg Pablo

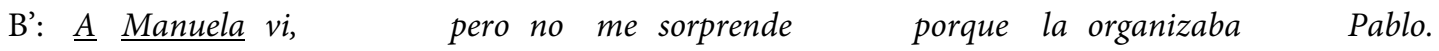
to Manuela see-past.1sg but not CL surprise-pres.3sg because it organise-past.3sg Pablo 'I saw Manuela, but that was no surprise since it was organized by Pablo.'

(16) A: ¿A cuántos alumnos examinaste en junio?

'How many students did you examine in June?'

B: Examiné $\underline{a} \underline{25}$ estudiantes. Era lo que esperaba.

examine-past.1sg to 25 students. be-past.3sg the what expect-past.1sg

B': $\underline{A} \underline{25}$ estudiantes examiné. Era lo que esperaba.

to 25 students examine-past.1sg. be-past.3sg the what expect-past.1sg

'I examined 25 students. It was what I expected.' 


\section{Object as CF}

(17) A: Ángela está comiendo salchichas.

'Angela was eating sausages.'

B: No, no. Está comiendo pasta, no salchichas.

No, no. be-pres.3sg eating pasta, not sausages

B': No, no. Pasta está comiendo, no salchichas.

No, no. pasta be-pres.3sg eating, not sausages

'No, no. She is eating pasta, not sausages.'

(18) A: Pilar Eyre ha ganado el Premio Planeta este año.

'Pilar Eyre has won the Planeta Prize this year?'

B: ¡Anda ya! Lo ganó Lorge Zepeda, no Pilar Eyre.

walk-imp already it win-past.3sg Jorge Zepeda, not Pilar Eyre

B’: ¡Anda ya! Lorge Zepeda lo ganó, no Pilar Eyre. walk-imp already Jorge Zepeda it win-past.3sg, not Pilar Eyre 'No way! Jorge Zepeda won it, not Pilar Eyre.'

\section{Object as MF}

(19) A: ¿A cuántos alumnos examinaste en junio?

'How many students did you examine in June?'

B: Examiné a $\underline{25}$ estudiantes. No era lo que esperaba, pues en clase eran 100. examine-past.1sg to 25 students not be-past.3sg the what expect-past since in class be-past.3sg 100

B': $\underline{\text { 2 } 25}$ estudiantes examiné. No era lo que esperaba, pues en clase eran 100. to 25 students examine-past.1sg not be-past.3sg the what expect-past since in class be-past.3sg 100 'I examined 25 students. It was not what I expected since there were more than 100 students in my class.'

(20) A: ¿Qué está comiendo Ángela?

'What is Angela eating?'

B: Está comiendo pasta. Y me sorprende un montón, porque no le gusta nada. be-pres.3sg eating pasta and CL surprise-pres.3sg a big deal since not her like-pres.3sg at.all

B': Pasta está comiendo. Y me sorprende un montón, porque no le gusta nada. pasta be-pres.3sg eating and CL surprise-pres.3sg a big deal since not her like-pres.3sg at.all 'She is eating pasta and it does surprise me since she doesn't like it at all.'

For the sake of clarity, I have divided the data into five groups depending on the type of focus involved in the relevant sentence. In the first two groups either the subject or the object has the discourse function of IF. For examples in (13) and (14) a transitive verb is used and the reply in B shows the use of postverbal subject with a clear IF function, whereas that in B' illustrates the use of preverbal subject performing the role of IF as well. Sentences in (12) include the intransitive (unaccusative) verb ir 'go', but the discourse category of the only argument of this verb is also that of IF.

The third group contains IF on the object. Sentences in (14) convey new information via a non-animate object, whereas sentences in (15) and (16) involve IF developed by a human DP 
object, thereby requiring personal $a$. The reply in B shows an in-situ IF, hence postverbal object, while the reply in B' displays the possible use of a fronted IF.

The fourth set of sentences represent CF, making clear its contrastive flavour by inserting the alternative with explicitly negated. Again the reply in B involves in-situ CF, whereas that in B' contains a fronted CF. Finally, the fifth group illustrates MF, both in situ (reply B) and fronted (reply B'). The mirative interpretation is induced by explicitly inserting the unexpected reaction against the assertion where MF has been used.

\section{Results and discussion}

In this section I present the results of the experiment carried out among SPS and SS speakers. Each different discourse category and its distinct variants will be followed by a brief discussion of the figures obtained. Figures include the number of speakers who gave a positive answer (hence they have selected OK as opposed to ?? and ${ }^{\star}$ ) about the grammaticality of the relevant construction, alongside the percentage represented by this group of participants.

Speakers were faced with sentences in which the subject of a transitive verb functioned as IF. In an SVO language such as Spanish, the preverbal position for a subject does not necessarily indicate that it is dislocated in the CP-system. It may as well be placed in spec-TP. As a consequence, with no other device than the context inducing the focus reading, speakers avoid the preverbal position and clearly prefer the postverbal position (for both SS with $82 \%$, and SPS with $78 \%$ of OK answers), which has been described in the literature as unambiguously reserved for IF-subjects (Zubizarreta 1999, López 2009, Ortega-Santos 2006), as Table 1 shows. ${ }^{8}$

Table 1: IF on subject with transitive verbs

\begin{tabular}{lll}
\hline & IF on subject (SPS) & \\
Position of Focus & Preverbal IF & Postverbal IF \\
Grammaticality & $48 \%$ & $78 \%$ \\
& $(13 / 27)$ & $(21 / 27)$ \\
& IF on subject (SS) & \\
Position of Focus & Preverbal IF & Postverbal IF \\
Grammaticality & $52 \%$ & $82 \%$ \\
& $(17 / 33)$ & $(27 / 33)$ \\
\hline
\end{tabular}

The figures obtained in the grammaticality judgement task confirm the validity of this analysis. However, the preverbal position for IF is not considered totally ungrammatical for both SS and SPS speakers.

The degree of acceptability grows higher with IF-subjects of unaccusative verbs, as shown in Table 2.

\footnotetext{
8 As pointed out by an anonymous reviewer, prosody will help disambiguate this double reading of preverbal subjects. However, analysing the prosody of different types of foci falls outside the scope this paper and it is part of my own ongoing research.
} 
Table 2: IF on subject with intransitive (unaccusative) verbs

\begin{tabular}{lll}
\hline & IF on subject (SPS) & \\
Position of Focus & Preverbal IF & Postverbal IF \\
Grammaticality & $63 \%$ & $96 \%$ \\
& $(17 / 27)$ & $(26 / 27)$ \\
& IF on subject (SS) & \\
Position of Focus & Preverbal IF & Postverbal IF \\
Grammaticality & $18 \%$ & $94 \%$ \\
& $(6 / 33)$ & $(31 / 33)$ \\
\hline
\end{tabular}

Since Burzio (1986), it is generally accepted that subjects of unaccusative verbs are generated as their complements. Hence an SV analysis of these constructions is not available in out-of-theblue sentences. Rather, the most natural pattern for unaccusatives is VS, where the subject is part of the all-focus interpretation of the sentence. However, the very same position is used for IF. In other words, as displayed in Table 2, there is a conflation of the informationally unmarked and marked positions in the sentence used in the test, which explains why so many informants rated the sentence as fully grammatical (94\% for SS; $96 \%$ for SPS). On the other hand, the preverbal position for IF-subjects is less natural than the corresponding postverbal one in SPS, yet it is still acceptable for most speakers (63\%), in clear opposition to SS (only 18\%).

In Tables 3 and 4 a different picture is illustrated. In Tables 1 and 2, the focused constituent was the subject, whose canonical position is preverbal except for unaccusative verbs. To confirm my claim that IF may involve movement to $\mathrm{CP}$ is quite tricky for subjects since from a linear point of view there is no difference between a subject being in TP or in CP. To sort out this problem, Tables 3 and 4 show the figures obtained for data where the focused element is the object (either a non-animate or human object). If the object is preverbal, it means that it has been moved to the LP.

Table 3: IF on non-animate object

\begin{tabular}{lll}
\hline & IF on non-animate object (SPS) & \\
Position of Focus & Preverbal IF & Postverbal IF \\
Grammaticality & $74 \%$ & $93 \%$ \\
& $(20 / 27)$ & $(25 / 27)$ \\
& IF on non-animate object (SS) & \\
Position of Focus & Preverbal IF & Postverbal IF \\
Grammaticality & $18 \%$ & $91 \%$ \\
& $(6 / 33)$ & $(30 / 33)$ \\
\hline
\end{tabular}

Table 4: IF on human object

\begin{tabular}{lll}
\hline & IF on human object (SPS) & \\
Position of Focus & Preverbal IF & Postverbal IF \\
Grammaticality & $81 \%$ & $85 \%$ \\
& $(22 / 27)$ & $(23 / 27)$ \\
& IF on human object (SS) & \\
Position of Focus & Preverbal IF & Postverbal IF \\
Grammaticality & $21 \%$ & $91 \%$ \\
& $(7 / 33)$ & $(30 / 33)$ \\
\hline
\end{tabular}


As is clear, regardless of the non-animate or human status of the object, SS still uses the postverbal position for IF, which complies with the Nuclear Stress Principle advocated for in Zubizarreta (1998) to identify IF. 91\% of SS informants are inclined to employ the postverbal position for IF-objects. The percentage for preverbal objects with an IF function is quite low in SS (approximately 20\%). In contrast, SPS speakers show no clear preference for postverbal IF, though the figure obtained in this category are a bit higher than in preverbal IF. Yet, moved objects as IF is quite productive in SPS (ranging from $74 \%$ to $81 \%$ ), which makes valid my claim that SPS makes use of a specific position for IF in the LP.

To distinguish IF from other types of foci, sentences containing Contrastive Focus and Mirative Focus were offered to the participants. Recall that IF carries just one feature, namely [+ Foc], whereas CF and MF have a more complex featural array ([+ Contrast] and [+ Unexpectedness], respectively). The results are displayed in Table 5 for CF and Table 6 for MF:

Table 5: Contrastive Focus on object

\begin{tabular}{lll}
\hline & CF on object (SPS) & \\
Position of Focus & In-situ CF & Fronted CF \\
Grammaticality & $89 \%$ & $92 \%$ \\
& $(24 / 27)$ & $(25 / 27)$ \\
& CF on object (SS) & \\
Position of Focus & In-situ CF & Fronted CF \\
Grammaticality & $82 \%$ & $85 \%$ \\
& $(27 / 33)$ & $(28 / 33)$ \\
\hline
\end{tabular}

Table 6: Mirative Focus on object

\begin{tabular}{lll}
\hline & MF on object (SPS) & \\
Position of Focus & In-situ MF & Fronted MF \\
Grammaticality & $85 \%$ & $70 \%$ \\
& $(23 / 27)$ & $(19 / 27)$ \\
& MF on object (SS) & \\
Position of Focus & In-situ MF & Fronted MF \\
Grammaticality & $91 \%$ & $67 \%$ \\
& $(30 / 33)$ & $(22 / 33)$ \\
\hline
\end{tabular}

When informants were faced with data involving CF (whose discourse interpretation was clear because of the explicit mention of the denied part of the previous assertion), both a high position (preposed object) and a low position (in situ) were available for all speakers, independently of the variety. ${ }^{9}$ This is shown in Table 5 . Conversely, for MF there is some

9 I have not tested postverbal subjects with a CF interpretation in this survey. According to Ortega-Santos (2013: 112), in (at least some varieties of) Spanish, CF can occur in the right periphery, as illustrated in (i), his example:

(i) A. He oído que ayer Juan lamenó haber comenzado el doctorado. have-1st.sg heard that yesterday Juan regret-past.3sg to-have started the $\mathrm{PhD}$ 'I have heard that yesterday Juan regretted having started the PhD.'

B. Pero ¿qué dices? Ayer lamentó haber comenzado el doctorado PEDRO, (y no Juan). but what say-2.sg yesterday regret-past.3sg to-have begun the $\mathrm{PhD}$ Pedro, (and not Juan) 'What? Yesterday, it was Pedro, not Juan, who regretted having started the PhD.' 
preference to leave the element conveying the speaker's unexpectedness in situ, as put forth in Table 6. However, the high position is still an option in both SS and SPS, with $67 \%$ and $70 \%$ of positive answer respectively. Economy may be somehow the reason for this preference in that, under minimalist premises, Merge is preferred over Move when both compete in the same derivation (Castillo et al. 2009).

\section{Conclusions}

In this paper, I have shown that in some varieties of Spanish (SPS) a specific position for IF is available at the LP of the sentence. This position has always been argued to denote some sort of contrast. However, the data presented in this work support the view that the focus category detected in the CP may simply convey new information in SPS, thereby carry the feature [+Foc]. This position, however, is not activated in Standard Spanish, which confirms that microvariation in SPS (with respect to SS) affects the Information Structure/Syntax interface. This microparametric variation has been supported by experimental evidence in the form of a test run among SPS and SS informants.

This is an understudied area, at least for SPS. There are various gaps in our knowledge of microparametric variation in Spanish, given that syntax has paid more attention to the standard language (since judgements can be gathered more easily) and dialetology never had an emphasis on syntax.

\section{References}

Alexiadou, A., and E. Anagnostopoulou. 1998. Parametrizing AGR: Word order, V-movement and EPP checking. Natural Language and Linguistic Theory 16: 491-539.

Alvar, M. 2004. Estudios sobre las hablas meridionales. Granada: Universidad de Granada.

Âmbar, M. 1999. Aspects of the syntax of focus in Portuguese. In G. Rebuschi, and L. Tuller (eds.), The grammar of focus, 23-53. Amsterdam/Philadelphia: John Benjamins.

Barbosa, P. 1995. Null subjects. PhD. diss., Cambridge, MA, MIT.

Barbosa, P. 2001. On inversion in wh-questions in Romance. In A. Hulk, and J-Y Pollock (eds.), Romance inversion, 2-59. New York: Oxford University Press.

Beaver, D., and B. Clark. 2008. Sense and sensitivity: How focus determines meaning. Oxford: Blackwell Publishers.

Belletti, A. 2004. Aspects of the low IP area. In L. Rizzi, (ed.), The structure of CP and IP - The cartography of syntactic structures, Vol. 2, 16-51. Oxford/New York: Oxford University Press.

Bianchi, V. 2012. On 'mirative' focus fronting. Presentation given at The 1st GLUE Workshop in Univ. Rome La Sapienza, April 20, 2012.

Bianchi, V., and G. Bocci. 2012. Should I stay or should I go? Optional focus movement in Italian. In C. Piñon, (ed.), Empirical issues in syntax and semantics 9, 1-18. http://www.cssp.cnrs.fr/eiss9/eiss9.pdf

Bianchi, V., G. Bocci, and S. Cruschina. 2014. Focus fronting, unexpectedness, and the evaluative dimension, ms. http://ling.auf.net/lingbuzz/002166

This points to the fact that the very same positions used for IF can be employed for CF, which actually gives support to my proposal that the left periphery can also be used for IF. 
Bianchi, V., G. Bocci, and S. Cruschina. in press, Focus fronting and its implicatures. In E. Aboh, A. Hulk, J. Schaeffer, and P. Sleeman, (eds.), Romance languages and linguistic theory 2013: Selected papers from Going Romance, Amsterdam 2013, 1-20. Amsterdam: John Benjamins.

Biberauer, T., A. Holmberg, I. Roberts, and M. Sheehan. 2010. Parametric variation: Null subjects in minimalist theory. Cambridge: Cambridge University Press.

Bosque, I. 1980. Sobre la negación. Madrid: Cátedra.

Burzio, L. 1986. Italian syntax. Dordrecht: D. Reidel Publishing Company.

Castillo, J.C, J. E. Drury, and K. K. Grohmann. 2009. Merge over Move and the Extended Projection Principle: MOM and the EPP revisited. IBERIA: An International Journal of Theoretical Linguistics 1: 53-114.

Cinque, G. 1990. Types of A'-dependencies. Cambridge, MA: MIT Press.

Cruschina, S. 2012. Discourse-related features and functional projections. New York/Oxford: Oxford University Press.

Donati, C., and M. Nespor. 2003. From focus to syntax. Lingua 113: 1119-1142.

Frascarelli, M. 2007. Subjects, topics and the interpretation of referential pro: an interface approach to the linking of (null) pronouns. Natural Language and Linguistics 25: 691-734.

Frascarelli, M., and Á. L. Jiménez-Fernández. 2013. Contrast at the interfaces. Presentation at the Cambridge Comparative Syntax, in Cambridge, May 5, 2013.

Frascarelli, M., and F. Ramaglia. 2013. 'Phasing' contrast at the interfaces: A feature-compositional approach to topics. In V. Camacho-Taboada, Á. L Jiménez-Fernández, J. Martín-González, and M. Reyes-Tejedor, (eds.), Information structure and agreement, 55-82. Amsterdam/Philadelphia: John Benjamins.

Gallego, Á. 2007. Phase theory and parametric variation. Ph.D. diss., Barcelona, Universitat Autònoma de Barcelona.

Gussenhoven, C. 2007. Types of focus in English. In C. Lee, M. Gordon, and D. Büring (eds.), Topic and focus: Crosslinguistic perspectives on meaning and intonation, 83-100. Dordrecht: Springer.

Gutiérrez-Bravo, R. 2008. La identificación de los tópicos y los focos. Nueva Revista de Filología Hispánica 56: $362-401$.

Hernanz, M.L. 2011. Sobre la periferia de los infinitivos. In V. Escandell Vidal, and M. Leonetti, (eds.), 60 problemas de gramática, 248-255. Madrid: Akal.

Jiménez-Fernández, Á. L. 2015. Towards a typology of focus: Subject position and microvariation at the discourse-syntax interface. Ampersand 2: 49-60.

Jiménez-Fernández, Á. L., and S. İşsever. 2012. Deriving A/A'-effects in topic fronting: Intervention of focus and binding. In J. Błaszczak, B. Rozwadowska, and W. Witkowski, (eds.), Current issues in generative linguistics: Syntax, semantics and phonology, 8-25. Wroclaw, Center for General and Comparative Linguistics.

Kiss, K. É. 1998. Identificational focus versus information focus. Language 74: 245-273.

Kratzer, A. 2004. Interpreting focus: Presupposed or expressive meanings? A comment on Geurts and van der Sandt. Theoretical Linguistics 30: 123-136.

Krifka, M. 2006. Association with focus phrases. In V. Molnár, and S. Winkler (eds.), The architecture of focus, 105-136. Berlin/New York: Mouton de Gruyter.

Leonetti, M., and V. Escandell. 2009. Fronting and verum-focus in Spanish. In A. Dufter, and D. Jacob (eds.), Focus and background in romance languages, 155-204. Amsterdam/Philadelphia: John Benjamins.

López, L. 2009. A derivational syntax for information structure. Oxford/New York: Oxford University Press.

Molnár, V. 2006. On different kinds of contrast. In V. Molnár, and S. Winkler (eds.), The architecture of focus, 197-234. Berlin/New York: Mouton de Gruyter.

Nespor, M., and M.T. Guasti. 2002. Focus-stress alignment and its consequences for acquisition. Lingue e linguaggio 1: 79-106.

Ortega-Santos, I. 2006. On postverbal subjects, PF and the Copy Theory: The Spanish case. In N. Sagarra, and A.J. Toribio, (eds.), Selected proceedings of the 9th Hispanic Linguistics Symposium, 56-66. Somerville, MA: Cascadilla Proceedings Project.

Ortega-Santos, I. 2013. Corrective focus at the right edge in Spanish. Lingua 131: 112-135.

Ortega-Santos, I. Forthcoming. Focus-related operations at the right edge in Spanish: Subjects and ellipsis. Amsterdam: John Benjamins. 
Piera, C. 1987. Sobre la estructura de las cláusulas de infinitivo. In V. Demonte, and M. Fernández Lagunilla (eds.), Sintaxis de las lenguas románicas, 148-166. Madrid: Arquero.

Quer, J. 2002. Edging quantifiers. On QP-fronting in Western Romance. In C. Beyssade, R. Bok-Bennema, F. Drijkoningen, and P. Monachesi (eds.), Romance languages and linguistic theory 2000 [Current issues in linguistics 232], 253-270. Amsterdam/Philadelphia: John Benjamins.

RAE-ASALE. 2009/2011. Nueva gramática de la lengua española. Madrid: Espasa.

Remberger, E. 2014. A comparative look at focus fronting in Romance. In A. Dufter, and Á.S. Octavio de Toledo (eds.), Left sentence peripheries in Spanish: Diachronic, variationist and comparative perspectives, 383-418. Amsterdam: John Benjamins.

Rizzi, L. 1997. The fine structure of the left periphery. In L. Haegeman (ed.), Elements of grammar, 281-337. Dordrecht: Kluwer.

Roberts, I. 2012. On the nature of syntactic parameters: a programme for research. In C. Galves, S. Cyrino, R. Lopes, F. Sandalo, and J. Avelar (eds.), Parameter theory and linguistic change, 319-334. Oxford/New York: Oxford University Press.

Rooth, M. 1992. A theory of focus interpretation. Natural Language Semantics 1(1): 75-116.

Sprouse, J., and D. Almeida. 2011. The role of experimental syntax in an integrated cognitive science of language. In C. Boeckx, and K. Grohmann (eds.), The handbook of biolinguistics, 181-202. Cambridge: Cambridge University Press.

Uriagereka, J. 1988. On government. Ph.D. diss., Storrs, University of Connecticutt.

Vanrell, M. M., and O. Fernández Soriano. 2013. Variation at the interfaces in Ibero-Romance. Catalan and Spanish prosody and word order. Catalan Journal of Linguistics 12: 253-282.

Zubizarreta, M.L. 1998. Word order, prosody and focus. Cambridge, MA: MIT Press.

Zubizarreta, M.L. 1999. Las funciones informativas: Tema y foco. In I. Bosque, and V. Demonte (eds.), Gramática descriptiva de la lengua española, 4215-4244. Madrid: Espasa Calpe. 